\title{
Use of Oral Nutritional Supplements in Neurology: General Principles, Special Practices
}

\author{
Nörolojide Oral Nütrisyonel Supleman Kullanımı: Genel İlkeler, Özel Pratikler
}

\begin{abstract}
There is convincing scientific evidence that the use of oral nutritional supplements (ONS) is advantageous in patients with disabling neurologic diseases such as stroke, dementia, amyotrophic lateral sclerosis, multiple sclerosis or Parkinson's disease, and also in older patients with a diagnosis of malnutrition or just risk of malnutrition, and in all these cases accompanied with insufficient oral food intake or during a condition such as infection, trauma or hospitalization that may pose an increased malnutrition risk along. A wide spectrum of commercial formulas ensuring adequate patient adaptation and toleration are available. For ONS supply to be beneficial, a person at risk of malnutrition or with the diagnosis of malnutrition should consume ONS containing at least $400 \mathrm{kcal}$ of energy and 30 grams of protein per day for a minimum of 1 month. ONS should not reduce the amount of normal daily food intake. If useful, ONS should be continued within the scope of predetermined goals. Supplementation of ONS is an economical and useful neurology practice.
\end{abstract}

Keywords: Caloric intake, nutrition, malnutrition, supplementation, consistency

\section{$\ddot{O} \mathbf{z}$}

Yaşlı bireylerde ve inme, demans, amiyotrofik lateral skleroz, multipl skleroz veya Parkinson hastalığı gibi nörolojik hastalığı olanlarda malnütrisyon tanısı veya riski varsa ya da malnütrisyon riski oluşturabilecek enfeksiyon, travma veya hastane yatışı gibi hallerde oral gıda alımı yetersizliğ başladığında oral nütrisyonel supleman (ONS) kullanımının gündeme gelmesi gerektiği konusunda ikna edici bilimsel veri bulunmaktadır. Hastanın yeterli uyunç ve toleransını să̆layabilecek çok çeşitli ticari formül spektrumu vardır. ONS takviyesinin yararlı olabilmesi için malnütrisyon veya malnütrisyon riski olan kişide günde en az 400 kcal enerji ve 30 gram protein içeren formülün minimum 1 ay süre ile uygulanması gerekir. ONS tüketilen normal gıda miktarını azaltmamalıdır. Faydalı ise hedefler çerçevesinde devam edilmelidir. ONS takviyesi ekonomik ve faydalı bir nöroloji pratiğidir.

Anahtar Kelimeler: Kalori alımı, nütrisyon, malnütrisyon, takviye, kıvam

\section{Introduction}

Information on the use of oral nutritional caloric supplements, better known as oral nutritional supplements (ONS), in the clinical practice of neurology has not been presented in a specific order in the literature. However, the use of rational ONS in almost every acute or chronic neurological disease has the potential to positively affect clinical outcomes. In this article, the theoretical and practical aspects of the use of ONS in major neurologic indications for neurologists are summarized based on current developments.
Malnutrition in Neurology: Frequency and Consequences

"Malnutrition" or "malnutrition risk" are common collateral conditions encountered in the clinical practice of neurology. There are many medical, physical and social causes of malnutrition in patients, which are usually in combination. All chronic systemic and neurologic diseases, especially in the elderly, pose a risk for malnutrition. But among these, those that cause dementia and immobility are the first to come to mind. Malnutrition creates an increased risk of infection, delayed wound healing, a decline in muscle strength and mobility, and a tendency to depression. Those

Address for Correspondence/Yazışma Adresi: Mehmet Akif Topçuoğlu MD, Hacettepe University Faculty of Medicine, Department of Neurology, Neurology Intensive Care Unit, Ankara, Turkey

Phone: +90312305 1806 E-mail: mat@hacettepe.edu.tr ORCID: orcid.org/0000-0002-7267-1431

Received/Geliş Tarihi: 23.01.2021 Accepted/Kabul Tarihi: 24.04.2021 
with malnutrition are mostly admitted to health institutions and hospitals. Malnutrition causes relatively benign diseases such as flu and urinary tract infections to progress much more severely. Patients with malnutrition stay in hospital longer, and the incidence of complications is much higher. For these reasons, the presence of malnutrition should be determined in patients. This is only possible with a systematic screening (1).

\section{Who Should Do Malnutrition Screening in Neurology?}

It is not possible to talk about the consensus of medical societies in the context of malnutrition screening, diagnosis and management. We agree with the view clearly stated by the British National Institute for Health and Care Excellence that the patient's physician, that is, the physician treating their primary disease, also conducts the nutritional processes (2). Although prevention and treatment of malnutrition is a multi-disciplinary effort, when it develops in a neurologist's patient, the neurologist should have control. But this always requires concentration, adequate training, and accumulated experience. In this context, "training" includes, as a minimum, the comprehensive determination of nutritional needs, the knowledge and use of indications and nutritional support options, ethical and legal issues, and the calculation of the potential risks and benefits of the approach.

When and Under What Circumstances Should Malnutrition Screening be Performed in Neurology?

In the clinical practice of neurology, the presence of malnutrition should be reviewed in every patient with acute or chronic disability who comes for their first visit. Malnutrition should be screened in every patient aged over 65 years who comes for the first examination. Apart from this, conditions that should call malnutrition to mind, such as involuntary weight loss, inability to gain weight despite the desire, impaired wound healing, and skin structure fragility, should not be forgotten. In addition, any accompanying malnutrition should be identified in any new medical condition, including the common cold. In all types of acute conditions, the nutritional capacity of patients will affect medical management.

How Should Malnutrition Screening be Performed in Neurology?

To reveal the nutritional status, body mass index (BMI), adequacy of food intake and nutrition, and involuntary weight loss occurring within a certain period should be evaluated. Screening tools can be used for this purpose. An example of these is the Malnutrition Universal Screening Tool (MUST) (3). In MUST, BMI ("0" if above $20 \mathrm{~kg} / \mathrm{m}^{2}$, "1" if $20-18.5 \mathrm{~kg} / \mathrm{m}^{2}$, and " 2 " if below $18.5 \mathrm{~kg} / \mathrm{m}^{2}$ ), involuntary weight loss in the last $3-6$ months (" 0 " if below $5 \%$, " 1 " if $5-10 \%$ and " 2 " if $>10 \%$ ), and the presence and duration of acute condition/disease that may have nutritional effects ("2" points if the effect on nutrition will be more than 5 days) are scored and as a result, "0" point reflects "low risk" for malnutrition, 1 point "moderate risk" and " 3 " or above points "high" malnutrition risk (4). Although other scoring systems contain similar items, we believe that their use interchangeably is not efficient, because they are validated in different groups of people and patients. The European Society for Clinical Nutrition and Metabolism (ESPEN) recommends MUST for the determination of malnutrition risk in the community and adults, by the Mini
Nutritional Assessment is more suitable for the elderly (5). For hospitalized patients, the ESPEN recommends Nutritional Risk Screening (NRS) $(6,7)$, the American Society for Parenteral and Enteral Nutrition recommends Subjective Global Assessment, (8) and the British Association for Parenteral and Enteral Nutrition recommends Nutrition Screening Tools (9). However, it should be kept in mind that all nutritional status assessment scoring systems, including MUST, have low performance, especially in older patients, and are only one of the criteria used in clinical evaluation. Thus, although scoring tools are a good help, they should not replace the examination, and importantly, the physician.

\section{Diagnosis of Malnutrition and Malnutrition Risk}

The diagnosis of malnutrition is classically made using (i) BMI below $18.5 \mathrm{~kg} / \mathrm{m}^{2}$, (ii) involuntary weight loss of more than $10 \%$ in the last 3-6 months, or (iii) weight loss of more than $5 \%$ in the last 3-6 months in those with BMI between 18.5 and $20 \mathrm{~kg} / \mathrm{m}^{2}$ (2).

The Global Leadership Initiative on Malnutrition (GLIM), which integrates muscle mass loss into malnutrition, recommends a diagnosis of malnutrition if one of the phenotypic and etiologic criteria are met (10). The GLIM phenotypic criteria are "weight loss" (if there is $\geq 5 \%$ weight loss in the last 6 months or if there is $\geq 10 \%$ weight loss over 6 months), "low BMI" (BMI $<20 \mathrm{~kg} / \mathrm{m}^{2}$ below 70 years; BMI $<22 \mathrm{~kg} / \mathrm{m}^{2}$ above 70 years) and "loss of muscle mass" demonstrated by a valid method. The etiologic criteria of GLIM are the presence of an inflammatory condition with reduced nutrition or absorption from the gastrointestinal system (GIS).

The main conditions that pose a risk of malnutrition are; (i) not eating or not getting enough food for more than 5 days; (ii) a prediction that there will be an inability to eat or malnutrition in the next 5 days; (iii) reduced GIS absorption capacity; (iv) the loss of a high amount of nutrients; and (v) an increase in nutrient need due to catabolic conditions $(11,12)$.

\section{Clinical Effects of ONS Use}

The use of ONS should be planned in every older patient, regardless of whether they have a chronic neurologic disease, if there is a "malnutrition" or "chronic condition + malnutrition risk" and if nutritional goals have not been achieved with the precautions taken as a result of dietary consultation and food fortification "(food first approach)" (12). If there is a "malnutrition" or "malnutrition risk" in older patients who are hospitalized, nutrition and feeding with ONS should be optimized. Complication rates and re-hospitalization are reduced by adding ONS only in the hospital (12). If there is "malnutrition" or "malnutrition risk" in older people discharged from the hospital, ONS should be recommended to prevent functional regression with nutrition and weight optimization (12).

The effects of ONS on mortality reduction, weight gain or maintaining weight during hospitalization, fewer hospitalizations and fewer complications, and improving functional status have been demonstrated in a series of systematic meta-analyses conducted by the Cochrane group, mostly in hospitalized patients $(13,14,15,16)$. It should be reminded that many small controlled studies are testing the same hypothesis in the clinical nutrition science arena and that the examination of these by meta-analysis method is accepted by the scientific community as a valid method of generating knowledge. In the 2002 analysis of the Cochrane 
group, 2.464 patients who were the subjects of 31 studies were analyzed. With ONS, there was $2.4 \%$ more weight gain and the duration of hospital stay decreased by 3.4 days. It was noteworthy that the relative mortality rate decreased by an average of $33 \%$ (15). A similar meta-analysis was updated in 2005 on 2.790 patients from 47 studies, and weight gain was found to be $2.3 \%$ higher and hospital stay approximately 2 days less. In addition, the mortality reduction was $26 \%$ on average in this analysis (14). In the last analysis of the same group published in 2009, the number of studies reached 62 and the number of patients reached 10,187 , and weight gain with ONS use was similarly $2 \%$. (16) In these three analyses, it was determined that the beneficial effect of ONS use on mortality and hospital stay continued, but possibly due to increased awareness and nutritional fortification in the control group, it decreased over time. With ONS, weight loss was prevented and reversed in hospitalized patients and the length of hospital stay was shortened, and in-hospital mortality was reduced. In addition, a $14 \%$ reduction in in-hospital complications and a slight improvement in functional status were noted in the final analysis (16).

We see two randomized controlled trials for the benefit of ONS in hospitalized patients. The first is the "NOURISH trial" involving 652 patients aged over 65 years with varying degrees of malnutrition due to cardiopulmonary problems (17). Patients were randomized equally to the special ONS group or the control group. The special ONS group received 350 kilocalories, 20 grams of protein and 1.5 grams of hydroxy methylbutyrate (HMB) twice per day. The control group received 48 kilocalories, 12 grams of carbohydrate, and $10 \mathrm{mg}$ of vitamin C. As a result, at the end of the third month, an approximately $5 \%$ decrease in mortality of the special ONS group was detected. Accordingly, the death of one patient within three months could be prevented by administering ONS to approximately 20 older patients hospitalized for medical reasons. Although this striking result is expected to be confirmed by other studies, we also saw in the NOURISH trial that the amount of normal food taken with ONS was not reduced, patients gained an average of 820 grams more weight and this practice was very economical. The second study was the EFFORT trial involving 2088 inpatients at (NRS 200 score $\geq 3$ ). The patients were randomized equally to the study and control groups. The study group reached the protein and energy target with protocolized individual nutritional planning, whereas the control group, which was called the "appetite group" by the authors, received standard hospital meals (18). Of the study group, 91\% received ONS support, and this group received an average of $290 \mathrm{kcal}$ of energy and 10 grams more protein per day than the control group. In this study where the control group did not receive dietary consultation, the combined rate of worsening at the end of the first month (mortality, need for intensive care, nonelective hospitalization, major complication, obvious regression in functional status) was significantly lower in the study group (27\% to $23 \%)$. It was noteworthy that the mortality rate was significantly lower in the nutritionally optimized group at the end of the first month (7\% to $10 \%)$. Although it was free to receive enteral or parenteral nutritional support in this study, only 20 patients in the study group received them, and we could say that this striking effect was due to the administration of ONS.

\section{Nutritional Therapy and Supplement Indications in} Neurology

The use of ONS in neurologic diseases such as dementia, amyotrophic lateral sclerosis (ALS), stroke, Parkinson's disease (PD), multiple sclerosis (MS) and sarcopenia is discussed separately in this section due to the relatively large amount of available data.

Most of the more than 20 small-scale studies (number of patients 28-121) reported that the use of ONS in patients with dementia at various stages had generally positive results. An average of $3.5 \%$ weight (and $1.15 \mathrm{BMI} \mathrm{kg} / \mathrm{m}^{2}$ ) increase was found with dosages between $125-680 \mathrm{kcal} /$ day and once in the morning for varying periods ( 3 weeks to 1 year). There was a decrease in weight in the control groups. In most studies, the addition of ONS was found to have a positive effect on mortality, in some on the rate of infection and hospitalization, and a few on pressure injury reduction. Based on all these studies and meta-analyses, it was concluded that although a positive effect on the clinical level could not be obtained in terms of slowing down cognitive impairment and functional decline, nutritional deficit (caloric) and malnutrition (and their consequences) in dementia could be corrected or reduced with ONS $(19,20)$. In the meantime, it should be noted that the frequency of not continuing ONS for a long time in patients with dementia (>25\%) was slightly higher than in other patient groups (21). Based on these data, ESPEN strictly recommends ONS supplementation to improve nutritional status in dementia (22).

Nutritional status is a determining factor for "survival time" in patients with ALS. Survival time is shortened in patients who are already weakened $\left(\mathrm{BMI} \leq 18.5 \mathrm{~kg} / \mathrm{m}^{2}\right)$ or have significant $(>5 \%)$ weight loss at the time of diagnosis. If weight stabilization can be achieved in ALS with ONS (and subsequent enteral nutrition), survival time is prolonged (23). In patients with ALS with muscle fatigue and long eating time, it is recommended to fractionate the food, switch to energy-rich foods, and complete the deficiencies. If weight loss continues or begins despite these, ONS is recommended. If the patient cannot gain weight in close follow-up, enteral nutrition is recommended. Making this recommendation, ESPEN has added that there are insufficient data to confirm that ONS can improve survival in patients with ALS (1).

The use of ONS should be recommended for these reasons in patients with malnutrition or older patients with stroke (1). The effect of ONS in patients with acute stroke with dysphagia and malnutrition or malnutrition risk was examined in the Feed or Ordinary Diet (FOOD-1) study (24). ONS with an energy density of $1.5 \mathrm{kcal} / \mathrm{cc}$ and containing 20 grams of protein was started on the fifth day on average and was given for approximately 34 days until discharge. No significant clinical benefit was detected in the ONS group compared with 2016 controls who received hospital meals and did not receive ONS. The $0.7 \%$ reduction in mortality with ONS was balanced by the same increase in the number of patients with poor functional prognosis (modified Rankin score 4 and 5). This result was recorded in the Neurological Clinical Practice as "Routine ONS is not required in patients with stroke without malnutrition" In the FOOD-1 study, only $8 \%$ of patients had malnutrition, and these were diagnosed by the attending physician without using objective criteria. Another important limitation of the study was that food intake in the groups was not monitored. 
Significant benefits of ONS in patients with stroke with malnutrition have been documented in small-scale studies. First, ONS can be given successfully: In a meta-analysis, it was shown that more energy (average $430 \mathrm{kcal} /$ day) and protein $(17$ grams more) could be provided, and this would have a positive reflection on nutritional parameters (25). Similarly, in a randomized study on this subject, although there was no statistically significant change in functional outcomes, a significant improvement was observed in the nutritional status as a result of four-week administration in patients with stroke of $400 \mathrm{cc}$ ONS containing $600 \mathrm{kcal}$ and 20 grams of protein per day, initiated in the first week following stroke (26).

Some studies have shown that ONS can increase and accelerate motor recovery in malnourished patients with stroke. This benefit may become evident with the use of high calorie and protein ONS. For example, in a small-scale randomized controlled study, significant improvement in functional independence scores and accelerated motor recovery were achieved with ONS application containing high energy and protein $(2 \mathrm{kcal} / \mathrm{cc}, 9$ grams protein $/ 100$ cc) compared with standard ONS ( $1 \mathrm{kcal} / \mathrm{cc}, 4$ grams protein/100 cc) (27). However, in these studies, a benefit at the level of statistical significance on mortality and dependence, in general, was not documented. However, the relative risk of pressure injury (mean $44 \%$ reduction in a meta-analysis) and hospital infection (mean $35 \%$ reduction in a meta-analysis) can be reduced with the use of ONS in acute stroke (28).

In PD, BMI and body fat mass decrease, whereas intramuscular adipose tissue increases (29). The frequency of malnutrition increases due to various reasons including anosmia, dyskinesia, dysphagia and gastric dysautonomia. It is known that up to one-quarter of patients with PD have a risk of malnutrition and twice this rate of malnutrition in these patients (30). There is an ONS indication in patients with PD with malnutrition or at risk of malnutrition. However, it should be noted that with ONS, many additional positive pathophysiologic effects can be achieved in the long term. For example, 20 grams/day of Whey isolate supplementation for six months was shown to increase plasma reduced glutathione, essential amino acid and branched-chain amino acid levels, and decrease homocysteine levels (31). On the other hand, in the PRO-LEADER study in which the effect of a high-Whey protein supplement (including 20 grams Whey, 2.8 grams leucine, 800 IU vitamin D) added twice a day for 1 month on the 6-minute walking test was examined in non-sarcopenic patients with PD who received inpatient physical therapy and rehabilitation, and it was concluded that walking distance was increased by 19 meters in the supplement group. This is highlevel evidence showing the benefit of adding nutritional support to a rehabilitation strategy (32).

Involuntary weight loss, malnutrition, and malnutrition risk increase as the level of neurologic involvement increases in patients with MS (33). Occult dysphagia should not be overlooked, especially in patients with cerebellar deficits. As a chronic disease, there may be many factors that lead to malnutrition in MS other than dysphagia. Malnutrition can cause symptomatic worsening of MS by increasing fatigue and spasm, impairing muscle strength and performance as well as adversely affecting the immune system. Therefore, there should be a strategy for determining dysphagia and nutritional status in the follow-up of patients with MS. In patients with MS with malnutrition or malnutrition risk, ONS should be recommended in addition to dietary adjustments.
Malnutrition hastens the time of clinical manifestation of sarcopenia and increases its severity (34). Sarcopenia, which is defined by the decrease in muscle strength and physical performance accompanying the decrease in muscle mass, can be prevented primarily by correcting malnutrition. Malnutrition and sarcopenia lead to reduced mobility, physical restraint and frailty, impaired respiratory function and a 3 -fold increase in falling. There is a 3.5fold increase in the risk of death in older patients with sarcopenia. In addition, patients with sarcopenia have more frequent and prolonged hospitalizations and a significant increase in the rate of major complications of all medical procedures. Therefore, it should be treated before the development of sarcopenia, especially in acute worsening and conditions that pose a risk of malnutrition (35).

On the other hand, sarcopenia is common in almost all neurodegenerative or neurologic diseases that cause immobility, especially dementia and stroke. As a rule, the frequency and severity of sarcopenia increase as the clinical stage of the neurologic disease worsens. Sarcopenia interacts additively with the neurologic deficit and negatively affects physical performance and quality of life. In addition, the situation worsens with many comorbid diseases such as diabetes, chronic obstructive pulmonary disease, cirrhosis, kidney failure, heart failure, cancer, orthopedic disabilities, or just advanced age, which are common in neurologic diseases. The solution is a diet with sufficient calories and high-quality protein, together with structural strength exercises.

\section{Starting Nutritional Support and Developing Optimal} Strategy

When nutritional support is decided for in a neurologic patient, it is necessary to start by transitioning to foods that are easy to eat, attractive, and tasty. The structure of the food should be in accordance with the patient's preference and if necessary, their eating should be physically helped. Correctible conditions such as chewing and swallowing disorders, dental problems, medications, pain and gastrointestinal problems that may contribute to malnutrition should be carefully reviewed and treated if possible. Dietician consultation is beneficial at this stage (Table 1).

For nutritional support, first, detection and modification recommendations are made for a balanced diet recommendation. The dietary modification includes; (i) sugar and fat supplements to foods to maximize oral intake (fortification and diversification); (ii) addition of extra nutritious snacks, high-calorie foods, and calorie and protein-rich drinks; (iii) making food edible (for example, adding biscuit to milk and adding sugar to it); and subsequent ONS addition (16). For successful outcomes, it is necessary to set reasonable and achievable goals, schedule them, and stage plans in close cooperation with the patients and their relatives $(2,12,36,37)$.

Dietitians who specialize in nutritional support in neurologic diseases should be called upon for support. First, the type and amount of energy, protein, liquid and fiber that the individual currently receives are determined. Planning is made by comparing this with the current need and level of use. In this context, individual activity level, GIS capacity and condition, clinical problems that are or may be present, the problem of refeeding syndrome, capacity, and time to reach the targets should be predicted. In our patients without critical and specific acute diseases, nutritional support should be started when these targets are not reached: Calories (target: $25-35 \mathrm{kcal} / \mathrm{kg} / \mathrm{day}$, including calories taken from proteins), protein (target: $0.8-1.5 \mathrm{~g} / \mathrm{kg}$, rarely higher) and water 
Table 1. ONS use algorithm

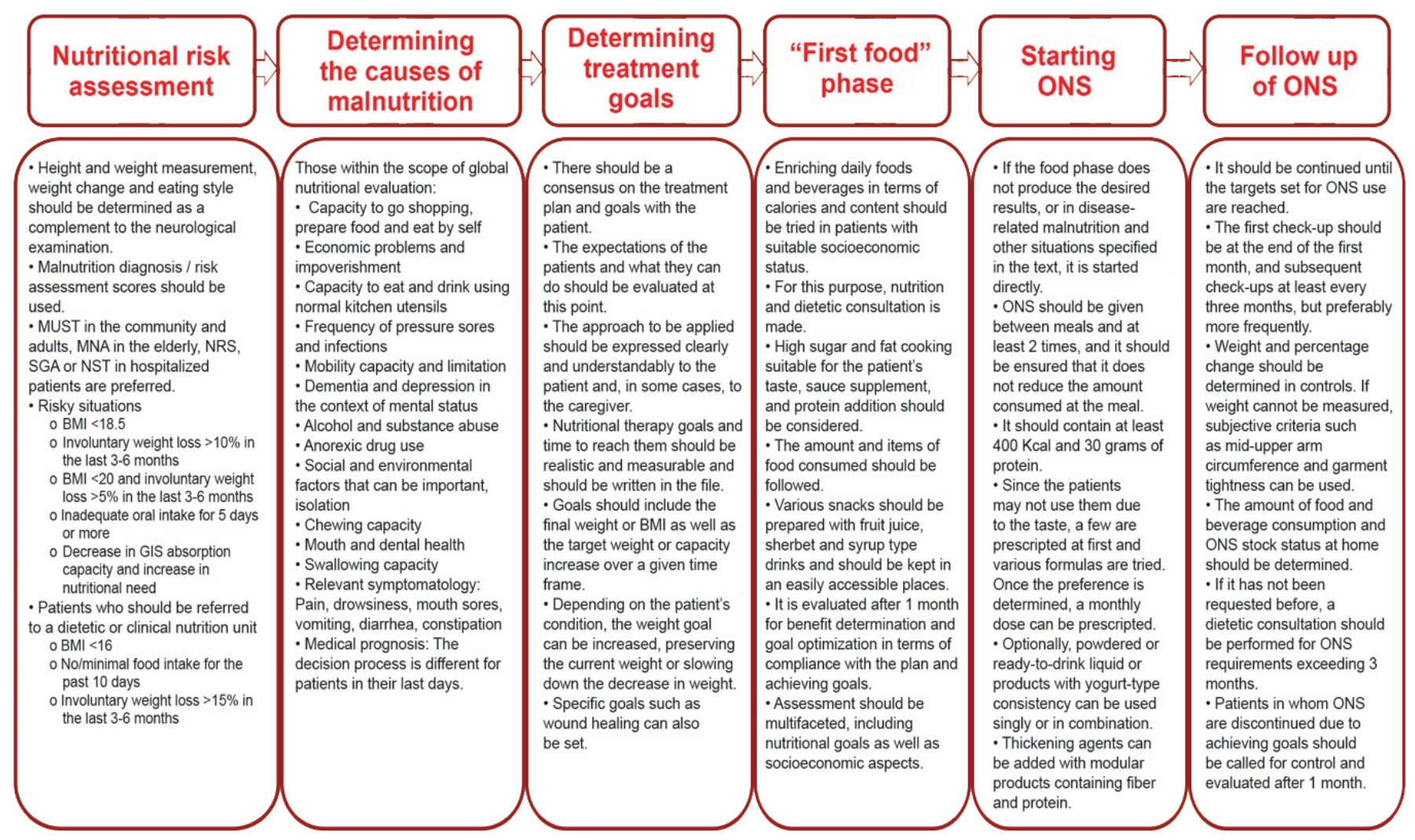

MUST: The Malnutrition Universal Screening Tool, MNA: Mini nutritional assessment, NRS: Nutritional Risk Screening, SGA: Subjective Global Assessment, NST: Nutrition Screening Tools, BMI: Body mass index, ONS: Oral nutritional supplement

(target: $30-35 \mathrm{cc} / \mathrm{kg} /$ day). It is ensured that nutritional support always contains a sufficient amount of electrolytes, minerals, fiber, and micronutrients $(2,12)$.

What are the Main Recommendations within the Scope of Enrichment of Nutrition?

The first stage of nutritional support in neurologic diseases is the enrichment of nutrition, which includes the whole applications to be continued after the ONS period. It should not be forgotten that these methods are indispensable for reducing calorie debt, especially in patients with poor ONS compliance. The main lines of nutritional enrichment are as follows: (1) Eat frequently, even if a little, in this context, at least three main meals and two or three snacks should be made; (2) supplementing with snacks with plenty of calories such as boiled eggs, small cakes and pastries, and semolina; (3) using full-fat and high-sugar products; (4) instead of normal liquids, using malt drinks, sweetened-milk-cream coffee and tea, hot chocolate and milk, fruit juice and rich soups. To enrich foods, it is necessary to prepare high-fat, cream, cheese and protein sauces during preparation. Daily sherbet, buttermilk, and soups should be prepared $(2,38)$.

\section{Is Enrichment of Nutrients Useful?}

The diet should also be enriched with ONS; however, ONS alone is not enough. In this respect, although the level of evidence is moderate, it is considered sufficient for clinical inference
$(1,12,39,40,41)$. In a meta-analysis of seven studies (588 patients) in which different fortification techniques were used in older patients with malnutrition risk, it was observed that an average of $200 \mathrm{kcal}$ and $7 \mathrm{~g}$ of protein could be achieved additionally. This amount was found to be beneficial in preventing malnutrition (39). In the review of the studies (3.186 patients) conducted in patients with malnutrition associated with the disease, an average of $3.75 \mathrm{~kg}$ was achieved with food fortification for more than 1 year (42). If ONS was added to dietary fortification, an average of $2.2 \mathrm{~kg}$ more weight gain was found. In a meta-analysis of ten studies (546 patients) examining the effect of enrichment in all hospitalized patients, it was documented that energy (250-450 $\mathrm{kcal} /$ day) and protein (12-16 g/day) intake could be increased (41). Similar positive rates in other diseases can be reached (43).

Use of Oral Nutritional Supplements: General Recommendations

As the main principle, ONS should be initiated in older patients who have a MUST score of 2 and above but do not reach their nutritional goals despite diet enrichment $(2,12,37,44)$. If there is a disease, it is recommended to start ONS with fortification without delay, by anticipating its consequences. ONS is an "addition" to diet and it is called a "supplement" It is used in conjunction with a natural and enriched eating program, not alone. ONS should not replace food. The amount of other food consumed with ONS is not expected to decrease (Table 1). 
ONS should always be considered for a certain period (usually 1-12 months). It should be continued according to the objective benefit. In other words, the nutritional status should be monitored at certain intervals for this purpose. The treatment goal, method of use, effectiveness evaluation and termination criteria should be decided together with the patients and their relatives.

The benefit of ONS depends on compliance. Compliance rates are $65-70 \%$ in the hospital and $80-85 \%$ outside the hospital (45). The choice of ONS is critical for success. Standard ONS is non-disease-specific, full or partial, liquid, semi-solid or powder products that contain multiple macro- and micronutrients. Their taste (milk, various fruit juice, yoghurt, sour, chocolate, coffee), formate (liquid, powder, pudding, nectar, high consistency), variety (high protein, fiber) and energy density (1-3, $4 \mathrm{kcal} / \mathrm{cc}$ ) vary (Table $1)$. The main carbohydrate source is often maltodextrin or glucose syrup. Although there are many different types of protein, most of them are cow's milk protein (casein), Whey protein (Whey), soy and a small portion of animal proteins. The lipid source is soybean oil, corn oil, palm seed or fruit, or animal fats and fish oil. Powdered nutritional supplements have the lowest cost, but also they are the most unfavorable group in terms of tolerance and compliance. Patients adapt better to ready-to-drink products. In this context, it should be noted that the effect of product change on compliance is possible.

The gusto of the patients is important. ONS formulas can be drunk alone or can be added to homemade beverages and syrups. Almost all can be refrigerated, making them more delicious. In the meantime, it should be known that ONS can be stored in the refrigerator for up to 24 hours and there is a chance of consumption several times to prevent waste.

ONS can be given in varying amounts depending on the patient's need, compliance, and tolerance. Some patients can meet all their food needs in this way, at least temporarily. However, for ONS to be beneficial, it should be kept in mind that ONS should provide "at least" $400 \mathrm{kcal} /$ day energy and $30 \mathrm{~g} /$ day protein in older patients with malnutrition or malnutrition risk. The duration of ONS application should be "at least" 1 month in older patients with malnutrition or under the risk of malnutrition. The minimum period for efficacy and benefit evaluation is 1 month $(12,22)$.

High-protein products contain protein with an energy amount of $20 \%$ or more. It can often rise to $30-35 \%$. High protein nutrition should be preferred in older patients with malnutrition, in the recovery period and sarcopenia. If the protein target cannot be reached with the product used, it may be considered to add a modular product (e.g. Protifar ${ }^{\circledR}: 2.5$ g per measure, containing 1.8 $\mathrm{g}$ of casein and $0.4 \mathrm{~g}$ Whey protein).

Hypercaloric products are used in cases where a fluid restriction is desired such as heart failure, renal failure, ascites, hypervolemic hyponatremia, and syndrome of inappropriate antidiuretic hormone secretion. On the other hand, energy-intensive products can be preferred in patients with low nutrient intake and severe neurodeficit and those with high-calorie needs. With these products, 30-50\% (500-700 kcal) more calories can always be achieved. However, if the reason for using concentrated formulas is not liquid restriction, it should be kept in mind that a sufficient amount of water should be given with concentrated formulas. This water or liquid supplement may be orally or parenterally, depending on the circumstances. These products are also preferred during the transition phase of nutrition from the enteral tube to the oral phase. No negativity is expected in GIS tolerance and glycemia control with energy-dense and high-protein products.

Fiber products should be preferred in the inactive older patients. Fourteen grams of fiber content should be offered for every $1000 \mathrm{kcal}$ intake. Standard products contain $5 \mathrm{~g}$ of fiber per liter, and around $15 \mathrm{~g}$ of fiber in pulp products. As long as there is no diarrhea or constipation, products containing a mixture of soluble and insoluble fibers are sufficient. If the daily fiber amount is not sufficient, it can be supplemented with a modular product (e.g. Optifibre ${ }^{\circledR} 5-12.5 \mathrm{~g} /$ day). The daily fluid intake of the patient should be calculated or at least roughly known. Typically, $1 \mathrm{cc}$ of fluid is given per calorie. This equates to approximately 35 cc per kilo. In ONS, water content changes according to calorie density and protein: Briefly, water content is $84 \%$ in formulas with $1 \mathrm{kcal} / \mathrm{cc} ; 82 \%$ in formulas with $1.2 \mathrm{kcal} / \mathrm{cc} ; 76 \%$ in formulas with $1.5 \mathrm{kcal} / \mathrm{cc}$, and $70 \%$ in formulas with $2 \mathrm{kcal} / \mathrm{cc}$. In other words, if $1 \mathrm{kcal} / \mathrm{cc}$ of standard product is given for 400 calories, $336 \mathrm{cc}$ of water is given, and $280 \mathrm{cc}$ of water is given with $2 \mathrm{kcal} / \mathrm{cc}$ hypercaloric product. Adding a thickener may be considered in the presence of swallowing problems or in the presence of oral frailty. Powder products based on starch (such as Multi-thick ${ }^{\circledR}$ ) or gum (such as Resource ${ }^{\circledR}$ Thicken-Up clear) or ready-to-use formulas (such as Fresubin Yocreme ${ }^{\circledR}$ ) can be used for this purpose.

There are specific products that are advantageous in cases of diabetes, kidney and hepatic failure, lung diseases, burns, perioperative conditions, supporting and accelerating wound healing or trauma. This variety may provide additional benefits for some patients (Table 2).

ONS Selection in Neurological Disease: General and Special Conditions

Standard caloric ONS is generally preferred in cases of stroke, dementia and MS. Since ONS is normally in a liquid consistency, it can also be used in patients with dysphagia by thickening with a thickener. There are ready-to-use ONS products in yoghurt consistency suitable for use as ONS.

It is thought that ONS to be selected for nutrition in ALS should have high calories. It is not clear that the content is enriched from lipid such as the ONS group produced for pulmonary diseases. In the LIPCAL-ALS study, using ONS with high calories and $100 \%$ lipid for 28 weeks $(4.5 \mathrm{kcal} / \mathrm{cc} ; 405 \mathrm{kcal} / \mathrm{day})$ was not shown to be beneficial in clinical indices including survival in 201 patients compared with the control group (46). However, another form of high-fat formulation (25\% fat, $50 \%$ carbohydrate, $15 \%$ protein) was already shown to have significantly lower efficacy than high calorie-high carbohydrate ONS $(3 \times 200 \mathrm{cc}, 1.5 \mathrm{kcal} / \mathrm{cc}$, $0 \%$ fat, $89 \%$ carbohydrate, $11 \%$ protein) (47). It is appropriate to follow ESPEN recommendations pending the completion of other ongoing randomized controlled trials on this topic. These recommendations are in accordance with neurology guidelines and do not recommend lipid-rich ONS $(48,49)$.

The levodopa (L-DOPA), which is the standard treatment of $\mathrm{PD}$, is absorbed from the one-third proximal part of the small intestine. It should be taken on an empty stomach, at least half an hour before a meal or at least 2 hours after a meal. Bioavailability of orally administered L-DOPA may decrease due to gastric emptying delay. Levodopa with L-type-neutral amino acid transporters (LAT) crosses the GIS mucosa and blood-brain barrier. LAT-1 is 


\begin{tabular}{|c|c|c|c|c|c|c|c|c|c|c|}
\hline & & $\mathrm{cc}$ & Calorie & Protein $\%$ & Lipid \% & $\mathrm{CHO} \%$ & Osm* & Fiber $\%$ & Energy & Protein $\mathrm{g}$ \\
\hline \multicolumn{11}{|l|}{ General } \\
\hline Fortimel & Drink & 500 & 1 & 16 & 35 & 49 & 385 & 0 & 500 & 20 \\
\hline Fortimel & Energy & 200 & 1.5 & 16 & 35 & 49 & 455 & 0 & 300 & 12 \\
\hline Fortimel & Energy multifibre & 200 & 1.54 & 16 & 34 & 47 & 455 & 2.9 & 308 & 12 \\
\hline Fortimel & Compact protein & 125 & 2.4 & 24 & 35 & 41 & 570 & 0 & 300 & 18 \\
\hline Fortimel & Compact fibre & 125 & 2.4 & 16 & 35 & 42 & 790 & 3.6 & 300 & 12 \\
\hline Ensure & Compact & 125 & 2.4 & 17 & 35 & 48 & 676 & 0 & 300 & 13 \\
\hline Ensure & Plus & 220 & 1.5 & 16.7 & 29.5 & 53.8 & 509 & 0 & 330 & 14 \\
\hline Ensure & $2 \mathrm{cal}$ & 200 & 2 & 16.8 & 40.1 & 42.1 & 527 & 1 & 400 & 17 \\
\hline Ensure & Plus fiber & 200 & 1.55 & 16.1 & 28.6 & 52.1 & 552 & 3.2 & 310 & 12 \\
\hline Fresubin & Original drink & 200 & 1 & 15 & 30 & 55 & 330 & 0 & 200 & 8 \\
\hline Fresubin & Energy drink & 200 & 1.5 & 15 & 35 & 50 & $355-405$ & 0 & 300 & 11 \\
\hline Fresubin & Energy fibre & 200 & 1.5 & 15 & 35 & 47.3 & $390-440$ & 2.7 & 300 & 11 \\
\hline Fresubin & 2 KCal fibre & 200 & 2 & 20 & 35 & 43.4 & $505-560$ & 2.6 & 400 & 20 \\
\hline Fresubin & $2 \mathrm{kcal}$ & 200 & 2 & 20 & 35 & 45 & $495-640$ & 0 & 400 & 20 \\
\hline Resource & 2.0 & 200 & 2 & 18 & 39 & 43 & 790 & 0 & 400 & 18 \\
\hline Resource & 2.0 fibre & 200 & 2 & 18 & 39 & 40.5 & 520 & 2.5 & 400 & 18 \\
\hline Resource & Protein & 200 & 1.25 & 30 & 25 & 45 & 390 & 0 & 250 & 19 \\
\hline Resource & Energy & 200 & 1.5 & 15 & 30 & 55 & 445 & 0 & 300 & 11 \\
\hline \multicolumn{11}{|l|}{ Special } \\
\hline & Supportan drink & 200 & 1.5 & 27 & 40 & 31 & $385-435$ & 2 & 300 & 20 \\
\hline & Nutrivigor & 220 & 1.5 & 24.3 & 28.8 & 44.8 & 557 & 1.7 & 330 & 20 \\
\hline & Cubitan & 200 & 1.28 & 31 & 25 & 44 & 625 & 0 & 256 & 20 \\
\hline & Oxepa & 500 & 1.5 & 16.5 & 55.6 & 27.9 & 384 & 0 & 750 & 31 \\
\hline & Prosure & 240 & 1.27 & 20.9 & 18.1 & 57.7 & 474 & 3.3 & 304.8 & 16 \\
\hline & Fresubin Hepa & 200 & 1.3 & 12 & 33 & 53.5 & 360 & 1.5 & 260 & 8 \\
\hline & Nepro & 200 & 1.8 & 14 & 43.2 & 42.8 & 456 & 1.56 & 360 & 13 \\
\hline & Vital & 200 & 1.5 & 18 & 33 & 53 & 630 & 0 & 300 & 14 \\
\hline & Impact RTD & 200 & 1.44 & 21 & 24 & 53 & 680 & 2 & 288 & 15 \\
\hline & Glucerna SR & 230 & 0.89 & 21 & 34 & 45 & 610 & 7.6 & 204.7 & 11 \\
\hline & Diasip & 200 & 1.04 & 19 & 33 & 45 & 365 & 3 & 208 & 10 \\
\hline & Diben & 200 & 1.5 & 20 & 42 & 35 & 350 & 3 & 300 & 15 \\
\hline & Resource diabet & 200 & 1.06 & 24 & 40 & 36 & 250 & 4 & 212 & 13 \\
\hline \multicolumn{11}{|c|}{ 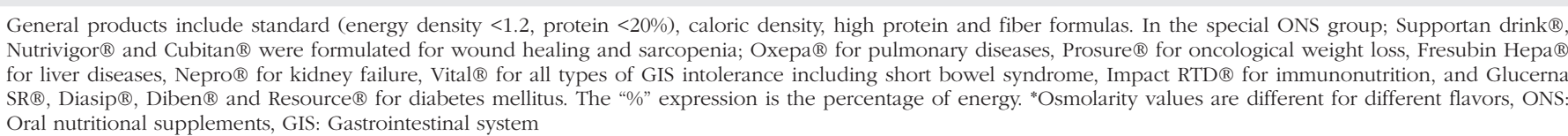 } \\
\hline
\end{tabular}

mainly found in the brain and carries major neutral amino acids (isoleucine, leucine, methionine, phenylalanine, tryptophan, tyrosine, and valine). LAT-2 is found in both the small intestine and the brain, it provides the transport of large and small neutral amino acids, namely serine, threonine, asparagine, glutamine, cysteine, isoleucine, leucine, phenylalanine, tryptophan, tyrosine, valine, methionine, histidine, glycine, and alanine. Also, both have an affinity for histidine (albeit positively charged). LAT-3 in the muscle can only transport leucine, valine, isoleucine, and phenylalanine. Levodopa bioavailability decreases when the blood level of these amino acids increases due to competition at the transporter level. Therefore, in some patients who develop severe motor fluctuations under L-DOPA treatment, the clinical response to L-DOPA can be significantly increased by restricting the daily intake to a protein level of $0.8 \mathrm{~g}$ per ideal body weight and shifting the proteins in the diet to the evening hours (50). In one study, it was shown that every 10 grams more protein consumption above the recommended amount of protein $(0.8 \mathrm{~g} / \mathrm{kg})$ led to an increase in L-DOPA daily requirement by $0.7 \mathrm{mg} / \mathrm{kg}$ (32).

In the "Parkinson protein redistribution diet", a maximum of $7 \mathrm{~g}$ of protein is taken during the day. Morning and lunch meals should be based on carbohydrates, vegetables, fruits and fat. At 
dinner, proteins such as eggs, fish, milk, meat and legumes are taken. Total protein consumed until going to bed is provided to reach the level of $0.8 \mathrm{~g}$ /ideal body weight-kg (51). That is, if protein-rich ONS is to be given, it is recommended to take it 2 hours after dinner. However, it is not possible to predict patient response for both protein restriction and redistribution. However, it can be said that patients with a long duration of illness and L-DOPA use but a short duration of motor fluctuations respond better (52). On the other hand, although most patients initially respond well, the effect may be temporary or worsen over time.

Nutritional approach and resistance training should be planned together for both prevention and recovery in sarcopenia (53). Prevention of sarcopenia is easier than maintenance therapy, but goals should be set rationally and relative independence in daily life should be centered. Adequate calorie and protein supply is essential in the nutritional approach. Protein supplement must contain leucine. Whey and dairy proteins in general are rich in leucine. Protein is recommended 3-4 times a day, 20-40 g before, during or after training. Each meal should contain a minimum of $2.5 \mathrm{~g}$ of leucine (37). According to the "Prot-Age study" group recommendations, the minimum protein requirement in healthy individuals is $1.0-1.2 \mathrm{~g} / \mathrm{kg} /$ day; $1.2-1.5 \mathrm{~g} / \mathrm{kg} / \mathrm{day}$ in those with acute and chronic diseases or aged over 65 years, and $2.0-2.5 \mathrm{~g} / \mathrm{kg} /$ day in severe disease and conditions, trauma and malnutrition. If the BMI is $>30 \mathrm{~kg} / \mathrm{m}^{2}$, the ideal body weight, and if it $<30 \mathrm{~kg} / \mathrm{m}^{2}$, usual weight should be used in determining this need (54). Based on the jointly evaluated results of the NOURISH study and smallscale studies, $\beta$ HMB supplementation is recommended for the prevention and rational treatment of sarcopenia $(17,55)$. It should be noted that the recommended supplementation is at a dosage of $3 \mathrm{~g} /$ day or $38 \mathrm{mg} / \mathrm{kg} /$ day at least twice, with no significant adverse effects up to $0.4 \mathrm{~g} / \mathrm{kg}$.

\section{Is ONS Economical to Use?}

In addition to the hospitalization period, the use of rational ONS in patients' own home or nursing home is also clearly economically advantageous $(56,57,58)$. Although the data quality of various studies on this subject is not very high, they are convincing. For example, it was shown in a study that if the duration of ONS use outside the hospital was less than three months, $9.2 \%$ of the expenses could be cut and that if it was three months or longer, an average of $5 \%$ cut in expenses could be achieved. With ONS, the rate of hospitalization was reduced by $16.5 \%$. In this study, the mortality reduction corresponded to a relative trend of $14 \%$. They were noted as the basic elements of the savings determined (57). In studies evaluating the economics of ONS use in hospitals, mostly based on surgical case series, the average cost reduction is given as $12.2 \%$. It was stated that this was due to an average of 2 days less hospitalization and a $35 \%$ reduction in minor complications (56).

\section{Final Words}

Studies evaluating the clinical efficacy of ONS use are heterogeneous in many respects, including the patient population (malnourished, malnutrition-only or normal), participating center and patient source (hospital-acquired or population-based), follow-up time, and outcome measures. The effect of ONS use was not evaluated within the scope of add-on in most studies because the control group did not receive food fortification. Nevertheless, the large number of studies and the centrality of the reviews make relatively reliable inferences. However, the need for large-scale randomized controlled studies on this subject remains (59). Regardless, it is a fact that many of our patients need nutritional risk assessment and treatment in the clinical practice of neurology. Malnutrition is common in all acute or chronic diseases of neurology, progresses and leads to disability on its own and worsens if it already exists. In this context, ONS represents an important treatment step.

\section{Ethics}

Peer-review: Externally peer-reviewed.

\section{Authorship Contributions}

Concept: M.A.T., E.M.A., E.S., Design: M.A.T., E.M.A., E.S., Data Collection or Processing: M.A.T., E.M.A., E.S., Analysis or Interpretation: M.A.T., E.M.A., E.S., Literature Search: M.A.T., E.M.A., E.S., Writing: M.A.T., E.M.A., E.S.

Conflict of Interest: M. Akif Topcuoglu received speakers' honorary from Abbott, Numil G1da Ürünleri, Fresenius Kabi and advisory board fees from Abbott and Fresenius Kabi. E. Murat Arsava received speakers' honorary from Abbott, Numil Gida Ürünleri, Fresenius Kabi and advisory board fees from Abbott, Numil Gıda Ürünleri, Fresenius Kabi. Esen Saka Topçuoğlu has nothing to declare.

Financial Disclosure: The authors declared that this study received no financial support.

\section{References}

1. Burgos R, Breton I, Cereda E, et al. ESPEN guideline clinical nutrition in neurology. Clin Nutr 2018;37:354-396.

2. Nutrition support for adults: oral nutrition support, enteral tube feeding and parenteral nutrition. Clinical guideline [CG32]. Available from: http:// www.nnng.org.uk/2017/07/update-on-nice-guideline-on-cg32-nutritionsupport-for-adults/

3. MUST Online Calculator - Malnutrition Universal Screening Tool of British Association for Parenteral and Enteral Nutrition. Last Accessed Date: 2020 19-2-2020. Available from: https://www.bapen.org.uk/screening-and-must/ must-calculator

4. Stratton RJ, Hackston A, Longmore D, et al. Malnutrition in hospital outpatients and inpatients: prevalence, concurrent validity and ease of use of the 'malnutrition universal screening tool' ('MUST') for adults. Br J Nutr 2004;92:799-808.

5. Vellas B, Guigoz Y, Garry PJ, et al. The Mini Nutritional Assessment (MNA) and its use in grading the nutritional state of elderly patients. Nutrition 1999;15:116-122.

6. Kondrup J, Rasmussen HH, Hamberg O, Stanga Z, Ad Hoc EWG Nutritional risk screening (NRS 2002): a new method based on an analysis of controlled clinical trials. Clin Nutr 2003;22:321-336.

7. Kondrup J, Allison SP, Elia M, et al. ESPEN guidelines for nutrition screening 2002. Clin Nutr 2003;22:415-421.

8. Mueller C, Compher C, Ellen DM, American Society for P, Enteral Nutrition Board of D. A.S.P.E.N. clinical guidelines: nutrition screening, assessment, and intervention in adults. JPEN J Parenter Enteral Nutr 2011;35:16-24.

9. Weekes CE, Elia M, Emery PW. The development, validation and reliability of a nutrition screening tool based on the recommendations of the British Association for Parenteral and Enteral Nutrition (BAPEN). Clin Nutr 2004;23:1104-1112.

10. Cederholm T, Jensen GL, Correia M, et al. GLIM criteria for the diagnosis of malnutrition - A consensus report from the global clinical nutrition community. Clin Nutr 2019;38:1-9.

11. Gomes F, Schuetz P, Bounoure L, et al. ESPEN guidelines on nutritional support for polymorbid internal medicine patients. Clin Nutr 2018;37:336353.

12. Volkert D, Beck AM, Cederholm T, et al. ESPEN guideline on clinical nutrition and hydration in geriatrics. Clin Nutr 2019;38:10-47. 
13. Milne AC, Avenell A, Potter J. Oral protein and energy supplementation in older people: a systematic review of randomized trials. Nestle Nutr Workshop Ser Clin Perform Programme 2005;10:103-125.

14. Milne AC, Avenell A, Potter J. Meta-analysis: protein and energy supplementation in older people. Ann Intern Med 2006;144:37-48.

15. Milne AC, Potter J, Avenell A. Protein and energy supplementation in elderly people at risk from malnutrition. Cochrane Database Syst Rev 2002;CD003288.

16. Milne AC, Potter J, Vivanti A, Avenell A. Protein and energy supple mentation in elderly people at risk from malnutrition. Cochrane Database Syst Rev 2009:CD003288

17. Deutz NE, Matheson EM, Matarese LE, et al. Readmission and mortality in malnourished, older, hospitalized adults treated with a specialized oral nutritional supplement: a randomized clinical trial. Clin Nutr 2016;35:1826.

18. Schuetz P, Fehr R, Baechli V, et al. Individualised nutritional support in medical inpatients at nutritional risk: a randomised clinical trial. Lancet 2019;393:2312-2321.

19. Allen VJ, Methven L, Gosney MA. Use of nutritional complete supplements in older adults with dementia: systematic review and meta-analysis of clinical outcomes. Clin Nutr 2013;32:950-957.

20. Tangvik RJ, Bruvik FK, Drageset J, Kyte K, Hunskar I. Effects of oral nutrition supplements in persons with dementia: a systematic review. Geriatr Nurs 2020;42:117-123.

21. Hines S, Wilson J, McCrow J, Abbey J, Sacre S. Oral liquid nutritional supplements for people with dementia in residential aged care facilities. Int J Evid Based Healthc 2010;8:248-251.

22. Volkert D, Chourdakis M, Faxen-Irving G, et al. ESPEN guidelines on nutrition in dementia. Clin Nutr 2015;34:1052-1073.

23. Silva LB, Mourao LF, Silva AA, et al. Effect of nutritional supplementation with milk whey proteins in amyotrophic lateral sclerosis patients. Arq Neuropsiquiatr 2010;68:263-268.

24. Dennis M, Lewis S, Cranswick G, Forbes J, Collaboration FT. FOOD: a multicentre randomised trial evaluating feeding policies in patients admitted to hospital with a recent stroke. Health Technol Assess 2006;10:iii-iv, ix-x, 1-120.

25. Geeganage C, Beavan J, Ellender S, Bath PM. Interventions for dysphagia and nutritional support in acute and subacute stroke. Cochrane Database Syst Rev 2012;10:CD000323.

26. Gariballa SE, Parker SG, Taub N, Castleden CM. A randomized, controlled, a single-blind trial of nutritional supplementation after acute stroke. JPEN J Parenter Enteral Nutr 1998;22:315-319.

27. Rabadi MH, Coar PL, Lukin M, Lesser M, Blass JP. Intensive nutritional supplements can improve outcomes in stroke rehabilitation. Neurology 2008;71:1856-1861.

28. Sakai K, Kinoshita S, Tsuboi M, et al. Effects of nutrition therapy in older stroke patients undergoing rehabilitation: a systematic review and metaanalysis. J Nutr Health Aging 2019;23:21-26.

29. van der Marck MA, Dicke HC, Uc EY, et al. Body mass index in Parkinson's disease: a meta-analysis. Parkinsonism Relat Disord 2012;18:263-267.

30. Wang YL, Wang YT, Li JF, et al. Body mass index and risk of Parkinson's disease: a dose-response meta-analysis of prospective studies. PLoS One 2015;10:e0131778.

31. Tosukhowong P, Boonla C, Dissayabutra T, et al. Biochemical and clinical effects of Whey protein supplementation in Parkinson's disease: a pilot study. J Neurol Sci 2016;367:162-170.

32. Barichella M, Cereda E, Pinelli G, et al. Muscle-targeted nutritional support for rehabilitation in patients with parkinsonian syndrome. Neurology 2019;93:e485-e496. doi: 10.1212/WNL.0000000000007858. Epub 2019 Jul 5 .

33. Redondo Robles L, Pintor de la Maza B, Tejada Garcia J, et al. Nutritional profile of multiple sclerosis. Nutr Hosp 2019;36:340-349.

34. Beaudart C, Sanchez-Rodriguez D, Locquet M, et al. Malnutrition as a Strong Predictor of the Onset of Sarcopenia. Nutrients 2019;11:2883.

35. Cruz-Jentoft AJ, Sayer AA. Sarcopenia. Lancet 2019;393:2636-2646.

36. Guidelines for Prescribing Oral Nutritional Supplements in Adults Last Accessed Date: 02.02.2020. Available from: https:/www.nottsapc.nhs.uk/ media/1111/sip-feeds-full-guideline.pdf

37. A Guide to Managing Adult Malnutrition in the Community including a pathway for the appropriate use of Oral Nutritional Supplements
(ONS). Last Accessed Date: 02.02.2020. Available from: https://www. malnutritionpathway.co.uk/library/managing_malnutrition.pdf

38. Food First/Food Enrichment. Last Accessed Date: 18.02.2020. Available from: https://www.bapen.org.uk/nutrition-support/nutrition-by-mouth/ food-first-food-enrichment

39. Morilla-Herrera JC, Martin-Santos FJ, Caro-Bautista J, et al. Effectiveness of food-based fortification in older people. a systematic review and metaanalysis. J Nutr Health Aging 2016;20:178-184.

40. Baldwin C, Kimber KL, Gibbs M, Weekes CE. Supportive interventions for enhancing dietary intake in malnourished or nutritionally at-risk adults. Cochrane Database Syst Rev 2016;12:CD009840.

41. Mills SR, Wilcox CR, Ibrahim K, Roberts HC. Can fortified foods and snacks increase the energy and protein intake of hospitalised older patients? A systematic review. J Hum Nutr Diet 2018;31:379-389.

42. Baldwin C, Weekes CE. Dietary advice with or without oral nutritional supplements for disease-related malnutrition in adults. Cochrane Database Syst Rev 2011:CD002008.

43. Trabal J, Farran-Codina A. Effects of dietary enrichment with conventional foods on energy and protein intake in older adults: a systematic review. Nutr Rev 2015;73:624-633.

44. No Author Listed. What role for oral nutritional supplements in primary care? Drug Ther Bull 2018;56:90-93.

45. Hubbard GP, Elia M, Holdoway A, Stratton RJ. A systematic review of compliance to oral nutritional supplements. Clin Nutr 2012;31:293-312.

46. Ludolph AC, Dorst J, Dreyhaupt J, et al. Effect of high-caloric nutrition on survival in amyotrophic lateral sclerosis. Ann Neurol 2020;87:206-216.

47. Dorst J, Cypionka J, Ludolph AC. High-caloric food supplements in the treatment of amyotrophic lateral sclerosis: a prospective interventional study. Amyotroph Lateral Scler Frontotemporal Degener 2013;14:533-536.

48. Andersen PM, Abrahams S, Borasio GD, et al. EFNS guidelines on the clinical management of amyotrophic lateral sclerosis (MALS)--revised report of an EFNS task force. Eur J Neurol 2012;19:360-375.

49. Miller RG, Jackson CE, Kasarskis EJ, et al. Practice parameter update: the care of the patient with amyotrophic lateral sclerosis: drug, nutritional, and respiratory therapies (an evidence-based review): report of the Quality Standards Subcommittee of the American Academy of Neurology. Neurology 2009;73:1218-1226.

50. Cereda E, Barichella M, Pedrolli C, Pezzoli G. Low-protein and proteinredistribution diets for Parkinson's disease patients with motor fluctuations: a systematic review. Mov Disord 2010;25:2021-2034.

51. Wang L, Xiong N, Huang J, et al. Protein-restricted diets for ameliorating motor fluctuations in Parkinson's disease. Front Aging Neurosci 2017;9:206.

52. Virmani T, Tazan S, Mazzoni P, Ford B, Greene PE. Motor fluctuations due to interaction between dietary protein and levodopa in Parkinson's disease. J Clin Mov Disord 2016;3:8.

53. McKendry J, Currier BS, Lim C, et al. Nutritional supplements to support resistance exercise in countering the sarcopenia of aging. Nutrients 2021;12:2057.

54. Bauer J, Biolo G, Cederholm T, et al. Evidence-based recommendations for optimal dietary protein intake in older people: a position paper from the PROT-AGE Study Group. J Am Med Dir Assoc 2013;14:542-559.

55. Bear DE, Cruz-Jentoft AJ, Stout JR. beta-hydroxy-beta-methylbutyrate supplementation in older persons - an update. Curr Opin Clin Nutr Metab Care 2021;24:48-52.

56. Elia M, Normand C, Norman K, Laviano A. A systematic review of the cost and cost effectiveness of using standard oral nutritional supplements in the hospital setting. Clin Nutr 2016;35:370-380.

57. Elia M, Normand C, Laviano A, Norman K. A systematic review of the cost and cost effectiveness of using standard oral nutritional supplements in community and care home settings. Clin Nutr 2016;35:125-137.

58. Hugo C, Isenring E, Miller M, Marshall S. Cost-effectiveness of food, supplement and environmental interventions to address malnutrition in residential aged care: a systematic review. Age Ageing 2018;47:356-366.

59. Correa-Perez A, Abraha I, Cherubini A, et al. Efficacy of non-pharmacological interventions to treat malnutrition in older persons: A systematic review and meta-analysis. The SENATOR project ONTOP series and MaNuEL knowledge hub project. Ageing Res Rev 2019;49:27-48. 